\title{
Recent insights into the cellular mechanisms of acute pancreatitis
}

\author{
Laura I Cosen-Binker BD PhD, Herbert Y Gaisano MD
}

LI Cosen-Binker, HY Gaisano. Recent insights into the cellular mechanisms of acute pancreatitis. Can J Gastroenterol 2007;21(1):19-24.

In acute pancreatitis, initiating cellular events causing acinar cell injury includes co-localization of zymogens with lysosomal hydrolases, leading to premature enzyme activation and pathological exocytosis of zymogens into the interstitial space. This is followed by processes that accentuate cell injury; triggering acute inflammatory mediators, intensifying oxidative stress, compromising the microcirculation and activating a neurogenic feedback. Such localized events then progress to a systemic inflammatory response leading to multiorgan dysfunction syndrome with resulting high morbidity and mortality. The present review discusses some of the most recent insights into each of these cellular processes postulated to cause or propagate the process of acute pancreatitis, and also the role of alcohol and genetics.

Key Words: Alcoholic pancreatitis; Cholecystokinin; Exocytosis; Pancreatitis

\section{De récents aperçus des mécanismes cellulaires de la pancréatite aiguë}

\begin{abstract}
En cas de pancréatite aiguë, l'initiation d'événements cellulaires causant des lésions cellulaires acineuses inclut la colocalisation de proenzymes avec des hydrolases lysosomiales entraînant une activation enzymatique prématurée et une exocytose pathologique des proenzymes dans l'espace interstitiel. Ces phénomènes sont suivis de processus qui accentuent la lésion cellulaire, déclenchant des médiateurs inflammatoires aigus, intensifiant le stress oxydatif, compromettant la microcirculation et activant les rétroactions neurogènes. Ces événements localisés évoluent ensuite vers une rétroaction inflammatoire systémique provoquant un syndrome de dysfonctionnement multiviscéral entraînant un taux de morbidité et de mortalité élevé. La présente analyse expose certains des aperçus les plus récents sur chacun de ces processus cellulaires qu'on pense causer ou propager le processus de pancréatite aigu, et également le rôle de l'alcool et de la génétique.
\end{abstract}

\section{PREMATURE ACTIVATION OF PANCREATIC ENZYMES WITHIN THE PANCREATIC ACINAR CELL}

The main role of the exocrine pancreas is to synthesize and secrete digestive enzymes, such as trypsinogen, into the intestinal lumen. In the lumen, trypsinogen is activated by duodenal enterokinase into trypsin, which is then capable of activating other pancreatic enzymes to collectively perform nutrient digestion (1). However, in acinar cells, these enzymes are maintained in inactive proforms (ie, trypsinogen) within the zymogen granules (ZGs) by inhibitors such as serine protease inhibitor, Kazal type 1 (SPINK1) (2). Inadvertently, activated enzymes, particularly trypsin, are cleaved by cytosolic enzyme Y and mesotrypsin (3). Because optimal $\mathrm{pH}$ levels and $\mathrm{Ca}^{2+}$ concentrations are required to activate the enzymes, a controlled $\mathrm{pH}$ range within the $\mathrm{ZG}$ is maintained by a ZG membrane-bound proton pump and a vacuolar ATPase (4), and low cytosolic $\mathrm{Ca}^{2+}$ concentration is maintained by $\mathrm{Ca}^{2+}$ sequestration into intracellular stores within a smooth endoplasmic reticulum compartment by a $\mathrm{Ca}^{2+}$ ATPase (5).

The current dogma for the pathogenesis of acute pancreatitis is the premature activation of trypsinogen within the pancreatic cell $(6,7)$. The major established experimental model of mild acute pancreatitis is the hyperstimulation (cholecystokinin [CCK] or its analogue cerulein/carbachol) model $(6,7)$, which leads to missorting and co-localization of zymogens with lysosomal cathepsin B within large cytoplasmic vacuoles, where trypsinogen is cleaved and activated $(6,7)$. Within this compartment, zymogen activation is favoured by an acidic $\mathrm{pH}$ that is effected by a hyperstimulationinduced translocation of cytosolic vacuolar ATPase (4). Hyperstimulation also causes a high and persistent rise in cytosolic $\mathrm{Ca}^{2+}$ concentration, which facilitates enzyme activation and large vacuole formation $(8,9)$. Pharmacological blockade of cathepsin B decreases necrosis in ceruleininduced pancreatitis (10). However, genetic deletion of cathepsin B in mice only partially prevented trypsinogen activation and did not completely abrogate cerulein-induced pancreatitis (11), indicating that additional factors must be involved in the pathogenesis of acute pancreatitis.

\section{BASOLATERAL EXOCYTOSIS INTO THE INTERSTITIAL SPACE}

Interstitial pancreatitis is a mild stage of clinical pancreatitis, which is due to the misdirection of pancreatic enzymes into the interstitial space (12). It was postulated that the normal release of enzymes into the ductal lumen from exocytosis of ZGs located at the apical pole becomes misdirected to the basolateral plasma membrane (PM), which then undergoes basolateral exocytosis (13). In fact, basolateral exocytosis in pancreatic acinar cells was demonstrated 20 years ago by

Department of Medicine, University Health Network and University of Toronto, Toronto, Ontario

Correspondence: Dr Herbert Y Gaisano, University of Toronto, Room 7226, Medical Science Building, 1 King's College Circle, Toronto,

Ontario M5S 1A8. Telephone 416-978-1526, fax 416-978-8765, e-mail herbert.gaisano@utoronto.ca

Received and accepted for publication March 24, 2006 
ultrastructural studies in not only hyperstimulation rodent models (13), but also in human pancreatitis (14). However, it was only recently that we were able to show basolateral exocytosis by real-time imaging of single ZG exocytosis in supramaximal CCK-stimulated rat pancreatic acinar cells (15). We have further elucidated the molecules mediating basolateral exocytosis $(15,16)$. It is well established that the fundamental mechanism controlling the fusion of membranes in all cell types revolves around the soluble $\mathrm{N}$-ethylmaleimide-sensitive factor attachment protein (SNAP) receptor (SNARE) hypothesis, which proposed that cytosolic $\mathrm{N}$-ethylmaleimide-sensitive factors and soluble SNAPs bind SNAREs on donor vesicles (v-SNAREs) and target membranes ( $t$-SNAREs) to form a series of multimolecular complexes (17). The union between $\mathrm{v}$ - and t-SNAREs ultimately mediates the fusion of the two membranes $(17,18)$. Specificity of membrane fusion events is due to the compartmental specificity of distinct sets of $v$-SNARE (vesicle-associated membrane proteins [VAMPs]) and t-SNARE (syntaxin and SNAP-25) proteins (19), and accessory proteins (particularly Munc18), which regulate the SNARE complex assembly (20). In the pancreatic acinar cell, we have identified the key SNARE proteins on the basolateral membrane (Syntaxin 4 and SNAP-23) and ZGs (VAMP), as well as the regulatory protein Munc18c $(15,16,21-23)$. Munc18c binds Syntaxin 4 to prevent its assembly with the other SNARE proteins $(24,25)$, but with supramaximal CCK stimulation, Munc18c dissociates from the basolateral PM, relieving Syntaxin 4 to bind to SNAP-23 and VAMP (most likely VAMP-8) (26) to effect basolateral exocytosis $(15,16)$. In fact, we observed Munc18c displacement from the basolateral PM not only in the rat model of hyperstimulation-induced pancreatitis (15), but also in human alcoholic chronic pancreatitis tissues (27).

Although the SNARE proteins bring the cognate membrane compartments in close proximity, $\mathrm{Ca}^{2+}$ is nonetheless the final fusogenic agent. $\mathrm{Ca}^{2+}$ can be released from different locations of the acinar cell. Physiological CCK stimulation acts on inositol 1,4,5-triphosphate receptors of $\mathrm{Ca}^{2+}$ stores that overlap the ZGs in the apical pole to effect normal apical exocytosis $(28,29)$. In contrast, hyperstimulation acts on ryanodine receptors (RYR), which release a distinct $\mathrm{Ca}^{2+}$ store located at the basolateral pole (30). This site of $\mathrm{Ca}^{2+}$ release is strategically located to effect basolateral exocytosis. Remarkably, depletion of RYR-sensitive $\mathrm{Ca}^{2+}$ stores or RYR blockade, in vitro and in vivo, reduced hyperstimulation-induced intracellular zymogen activation, but did not affect enzyme secretion (30). This intriguingly suggests that zymogens could already be activated within the ZGs before their release, by basolateral exocytosis into the interstitial space, which would initiate an inflammatory response.

\section{ROLE OF INFLAMMATORY MEDIATORS}

Acini undergoing injury release zymogens, particularly trypsin, that induce macrophages to synthesize and release proinflammatory cytokines, such as tumour necrosis factoralpha (TNF- $\alpha$ ) and interleukin-1 (IL-1) beta, which are capable of inducing neutrophil recruitment and activation within the pancreatic tissue $(31,32)$. Acinar cells themselves can synthesize cytokines, which amplify the local inflammatory response (33). TNF- $\alpha$ has direct actions on acini that mimic CCK hyperstimulation, including nuclear factorkappa B (NF- $\mathrm{KB})$ activation and disruption of the actin cytoskeleton; but unlike CCK, TNF- $\alpha$ can also induce apoptosis (34). NF- $\kappa \mathrm{B}$ is a transcription factor that promotes the expression of proinflammatory cytokines (35). Supramaximal CCK stimulation (hyperstimulation), in vitro or in vivo, causes NF- $\mathrm{KB}$ activation within acinar cells during the early phase of pancreatitis (36) by inducing $I \kappa B$, the enzyme degrading NF- $\kappa$ B proteolysis. Satoh et al (36) have revealed that $\mathrm{CCK}$-induced $\mathrm{I} \kappa \mathrm{B}$ degradation is partly mediated by novel protein kinase $\mathrm{C}$ isoforms delta and epsilon, which are activated by diacylglycerol, generated by phosphatidylinositol- and phosphatidylcholine-specific phospholipase C.

Zymogens and cytokines released by the inflamed pancreas into the ascitic fluid are absorbed into the circulation, leading to the systemic inflammatory response syndrome $(31,32,37)$. These molecules induce leukocyte recruitment, which in turn exacerbates the synthesis and release of proinflammatory mediators in distant targeted organs (ie, lung), with consequent multiorgan dysfunction syndrome (38). In fact, disease severity can be correlated to the level of these circulating cytokines (39). Consistent with the postulate that cytokines and NF- $\mathrm{KB}$ contribute to both local and systemic inflammatory response (40), pharmacological inhibition of NF- $\kappa$ B (40-42), leukocyte depletion (43) or genetic deletion of cytokine IL-1 $\beta$ (44), receptors to IL-1 type I or TNF- $\alpha$ type I (45) or intercellular adhesion molecule-1 (46) have uniformly decreased the severity of pancreatitis, including the associated lung injury (43).

Compromised pancreatic blood circulation also contributes to the pathogenesis of acute pancreatitis (47). A major factor modulating the pancreatic microcirculation is nitric oxide metabolism (48), which when altered in gene knockouts of nitric oxide synthase (49) or IL-18 (50), profoundly influences cerulein-induced pancreatitis (50).

\section{NEUROGENIC INFLAMMATION}

The perivaterian duodenum, the region where the pancreas meets the duodenum, has a very rich autonomic innervation (51). Any obstruction and/or irritative noxa in this region (ampulla of Vater) caused by gallstones, biliary sludge or endoscopic manoeuvres, stimulates primary sensory neurons which trigger autonomous arc reflexes (AARs), that initiate an acute, neurogenic inflammatory response in the pancreatic tissue (52). The AARs integrate the perivaterian duodenum autonomic nerve fibres with those from the celiac ganglion and bulbar-hypothalamic nuclei $(52,53)$. These sensory neurons in the pancreas contain unmyelinated, capsaicin-sensitive (type C) nerve fibres that release sensory peptides such as substance $P$, neurokinin $A$ and vasoactive intestinal peptides (52). These peptides act on mast cells, causing release of histamine and proinflammatory mediators, which are responsible for vasodilation and increased vascular permeability. This leads to edema and recruitment of neutrophils $(52,54,55)$. Stimulation of the AARs also induces a local, sympathetic overstimulation that acts on the pancreatic microcirculation, causing vasoconstriction and consequent ischemia-reperfusion injury (56). These AAR-mediated events are observed using biliopancreatic duct outlet exclusion-closed duodenal loops model (57). Using this model, in one study (57) topical lidocaine was 
able to interrupt the AARs, which remarkably ameliorated pancreatitis.

\section{FACTORS INFLUENCING RECOVERY AND REGENERATION AFTER PANCREATITIS}

A number of proteins within acinar cells act to protect the exocrine pancreas from injury or to facilitate its recovery. These proteins include heat shock proteins (Hsps), pancreatitis-associated proteins (PAPs) (58) and cytoskeletal actin (59). Hsp27, Hsp60, Hsp70 and Hsp90, present in the exocrine pancreas $(60,61)$, are stress-induced proteins inducible by hyperthermia (62) and water immersion (63). Both hyperthermia and water immersion protect against cerulein hyperstimulation and arginine-induced pancreatitis via their actions on Hsp27 and Hsp70 $(62,64)$. Hsp27, when phosphorylated, is able to inhibit trypsin activity as well as prevent degradation and disruption of the actin cytoskeleton, thereby hastening acini recovery after injury (65). In fact, transgenic mice overexpressing human Hsp27 or a constitutively phosphorylated mutant were resistant to ceruleininduced pancreatitis, which correlated with reduced trypsin activation and intact actin cytoskeleton (65). Hsp70 activation inhibits NF- $\kappa B$ activation in pancreatitis (66). PAP-1, whose levels are increased during pancreatitis (67), exhibits antiapoptotic and anti-inflammatory actions, primarily by reducing TNF- $\alpha$-induced apoptosis in acinar cells (68) and inhibiting TNF- $\alpha$-induced NF- $\mathrm{KB}$ activation in macrophages (69). PAP-1 also reduces leukocyte-induced lung injury during acute pancreatitis (70).

The following proteins are also elevated very early in the acinar cells during pancreatitis and can influence pancreatic regeneration. p8 is a nuclear phosphoprotein (71), which may act as a transcription cofactor involved in cell proliferation $(72,73)$. Interferon-inducible protein 15 is induced by interferons, alpha and delta, and inhibits cell proliferation (74). Vacuole membrane protein 1 is a proapoptotic factor that is associated with large cytoplasmic vacuoles $(75,76)$, one of the earliest morphological evidences of mild acute pancreatitis $(6,7)$. Mitochondrial dysfunction occurring during acinar injury results in ATP depletion and activation of poly (ADP-ribose) polymerase, which interferes with caspase-9 activation (77). This proapoptotic action of poly (ADP-ribose) polymerase is activated in cerulein-induced pancreatitis, and its pharmacological blockade inhibits pancreatic necrosis (77). The local inflammatory response can activate neural release of proteinase-activated receptor 2 , which has protective effects through actions on exocrine and duct regeneration and repair $(77,78)$. However, proteinaseactivated receptor 2 can also induce vasoconstriction of the microcirculation, followed by vasodilation due to its ability to release nitric oxide from endothelial cells, which collectively contributes to pancreatic ischemia-reperfusion injury (78).

\section{GENE MUTATIONS AND HEREDITARY PANCREATITIS}

Recurrent episodes of acute pancreatitis, particularly in the young, indicate a genetic origin (79). The main gene mutations associated with pancreatitis are in the following proteins: cationic trypsinogen (PRSS 1), the pancreatic secretory trypsin inhibitor or SPINK1, the cystic fibrosis transmembrane conductance regulator (CFTR), alpha-1antitrypsin, alcohol metabolizing enzymes and the human leukocyte antigen locus (80). Recurrent acute pancreatitis can also result from familial disorders of lipid metabolism (familial hypertriglyceridemia, familial hypercholesterolemia, congenital deficits in lipase lipoprotein or apolipoprotein C-II), calcium metabolism (hyperparathyroidism, familial hypercalcemia or hypocalciuria) and other disorders (homocystinuria or acute intermittent porphyria) (81).

PRSS 1 mutations cause excessive activation of cationic trypsinogen to occur within the acinar cell and consequent autodigestion of the pancreas (82). These cases of autosomal dominant hereditary pancreatitis are mostly linked to two missense mutations in the PRSS 1 gene on chromosome 7 (7q35), in exon 2 (N291) and exon $3(\mathrm{R} 122 \mathrm{H})$, with $80 \%$ penetrance $(78,81)$. These mutations also increase the risk of developing pancreatic adenocarcinoma by 50 times, particularly if the allele is of paternal origin and/or combined with smoking (83).

SPINK1 blocks the active site of trypsinogen (2). Most cases are associated with the N34S mutation in exon 3 of the SPINK1 gene located in chromosome $5 \mathrm{q}$ (2). Although $6 \%$ to $40 \%$ of patients diagnosed with idiopathic pancreatitis have a N34S mutation $(2,80)$, these mutations per se are not sufficient to induce pancreatitis, and they would require other environmental (ie, high alcohol intake) or genetic (ie, CFTR gene mutations) triggering factors $(80,84)$.

Cystic fibrosis is the most frequent autosomal recessive disease in the Caucasian population (one in every 2500 people) with a very high frequency of heterozygous carriers (one in 25 people) (79). The major mutation in the CFTR gene is situated in the long arm of chromosome 7 in $7 \mathrm{q} 31$ (83). The CFTR protein is a chloride channel on pancreatic ductal cells $(85,86)$, which when defective, reduces pancreatic ductal fluid flow, resulting in mucovisidosis and ductal obstruction, and leading to pancreatic insufficiency and episodes of pancreatitis $(86,87)$.

\section{ALCOHOL-INDUCED PANCREATITIS}

Alcohol is the most common cause of pancreatitis, but the precise mechanism of alcohol-induced pancreatic injury remains elusive (88). In fact, animal models with administration of alcohol acutely or chronically did not lead to pancreatitis (89). Instead, after alcohol feeding, pancreatitis can be induced by submaximal CCK, fat and viral infections (90-92). This suggests that alcohol either serves as a sensitizing factor or activates undefined 'susceptibility' factors, which predispose the exocrine pancreas to injury by triggering factors. As a sensitizing factor, animals that were put on an alcohol diet exhibited increased expression of cytokines and NF- $\mathrm{kB}$ activation upon low-dose CCK-8 stimulation (93). As a susceptibility mechanism, our recent report on pancreatic tissues obtained from a patient with mild alcoholic pancreatitis showed that exocytotic proteins in the acinar basolateral PM are perturbed; that we propose predisposed to pathological basolateral exocytosis that perpetuates the inflammatory process (27).

Nonetheless, alcohol has been shown to have direct effects on the exocrine pancreas. Alcohol metabolism in the acinar cells is similar to hepatocytes, including oxidative pathways generating acetaldehyde and nonoxidative pathways 
generating fatty acid ethyl esters $(94,95)$, both of which are toxic to acini. Reactive oxygen species are also generated, which alter actin filament polymerization to induce cytoskeletal disruption (96). Alcohol also causes hypoxia (97), as well as mitochondrial dysfunction and injury (98), which aggravates the ischemic-hypoxic injury caused by the already compromised microcirculation. Mitochondrial dysfunction perturbs $\mathrm{Ca}^{2+}$ release processes (99), which activate calpains, a cytosolic cysteine protease that targets the actin cytoskeleton (100), along with $\mathrm{Ca}^{2+}$-induced detrimental actions on zymogen activation and pathological exocytosis. Alcohol increases lysosome (101) and ZG fragility

\section{REFERENCES}

1. Pandol SJ. Pancreatic physiology. In: Sleisenger $\mathrm{MH}$,

Fordtran JS, eds. Gastrointestinal Disease, 5th edn. Philadelphia: WB Saunders Co, 1993:1585-600.

2. Witt H, Luck W, Hennies HC, et al. Mutations in the gene encoding the serine protease inhibitor, Kazal type 1 are associated with chronic pancreatitis. Nat Genet 2000;25:213-6.

3. Sahin-Toth M. The pathobiochemistry of hereditary pancreatitis: Studies on recombinant human cationic trypsinogen. Pancreatology 2001;1:461-5.

4. Waterford SD, Kolodecik TR, Thrower EC, Gorelick FS. Vacuolar ATPase regulates zymogen activation in pancreatic acini. J Biol Chem 2005;280:5430-4

5. Sutton R, Criddle D, Raraty M, Tepikin A, Neoptolemos JP, Petersen $\mathrm{OH}$. Signal transduction, calcium and acute pancreatitis. Pancreatology 2003;3:497-505.

6. Willemer S, Bialek R, Adler G. Localization of lysosomal and digestive enzymes in cytoplasmic vacuoles in caerulein-pancreatitis. Histochemistry 1990;94:161-70.

7. Steer ML, Meldolesi J. The cell biology of experimental pancreatitis. N Engl J Med 1988;316:144-50.

8. Kruger B, Albrecht E, Lerch MM. The role of intracellular calcium signaling in premature protease activation and the onset of pancreatitis. Am J Pathol 2000;157:43-50.

9. Raraty M, Ward J, Erdemli G, et al. Calcium-dependent enzyme activation and vacuole formation in the apical granular region of pancreatic acinar cells. Proc Natl Acad Sci USA 2000;97:13126-31.

10. Van Acker GJ, Saluja AK, Bhagat L, Singh VP, Song AM, Steer ML. Cathepsin B inhibition prevents trypsinogen activation and reduces pancreatitis severity. Am J Physiol Gastrointest Liver Physiol 2002;283:G794-800.

11. Halangk W, Lerch MM, Brandt-Nedelev B, et al. Role of cathepsin $\mathrm{B}$ in intracellular trypsinogen activation and the onset of acute pancreatitis. J Clin Invest 2000;106:773-81

12. Hartwig W, Jimenez RE, Werner J, Lewandrowski KB, Warshaw AL, Fernandez-del Castillo C. Interstitial trypsinogen release and its relevance on the transformation of mild into necrotizing pancreatitis in rats. Gastroenterology 1999;117:717-25.

13. Scheele G, Adler G, Kern H. Exocytosis occurs at the lateral plasma membrane of the pancreatic acinar cell during supramaximal secretagogue stimulation. Gastroenterology 1987;92:345-53.

14. Kloppel G, Dreyer T, Willemer S, Kern HF, Adler G. Human acute pancreatitis: Its pathogenesis in the light of immunocytochemical and ultrastructural findings in acinar cells. Virchows Arch A Pathol Anat Histopathol 1986;409:791-803.

15. Gaisano HY, Lutz MP, Leser J, et al. Supramaximal cholecystokinin displaces Munc18c from the pancreatic acinar basal surface, redirecting apical exocytosis to the basal membrane. J Clin Invest 2001;108:1597-611.

16. Gaisano HY. A hypothesis: SNARE-ing the mechanisms of regulated exocytosis and pathologic membrane fusions in the pancreatic acinar cell. Pancreas 2000;20:217-26.

17. Sudhof TC. The synaptic vesicle cycle: A cascade of proteinprotein interactions. Nature 1995;375:645-53.

18. Weber T, Zemelman BV, McNew JA, et al. SNAREpins: Minimal machinery for membrane fusion. Cell 1998;92:759-72.
(102), increases trypsinogen synthesis (103) and promotes zymogen activation (102). Alcohol can also activate 'neurogenic' mechanisms, specifically by increasing the sympathetic tone, which may result in chronic alteration in vagal-vagal tone, inducing cholinergic hyperstimulation of the pancreas (52), and spasms and dysfunction of the sphincter of Oddi (52).

FUNDING: The present study is supported by grants from the Alcoholic Beverage Medical Research Foundation and the National Institutes of Health (R21 AA015579-01A1).
19. McNew JA, Parlati F, Fukuda R, et al. Compartmental specificity of cellular membrane fusion encoded in SNARE proteins. Nature 2000;407:153-9.

20. Rizo J, Sudhof TC. SNAREs and Munc18 in synaptic vesicle fusion. Nat Rev Neurosci 2002;3:641-53.

21. Gaisano HY, Sheu L, Grondin G, et al. The vesicle-associated membrane protein family of proteins in pancreatic and parotid acinar cells. Gastroenterology 1996;111:1661-9.

22. Gaisano HY, Ghai M, Malkus PN, et al. Distinct locations of the syntaxin family of proteins in rat pancreatic acinar cells. Mol Biol Cell 1996; 7:2019-27.

23. Gaisano HY, Sheu L, Wong PP, Klip A, Trimble WS. SNAP-23 is located in the basolateral plasma membrane of rat pancreatic acinar cells. FEBS Lett 1997;414:298-302.

24. Tellam JT, Mcintosh S, James DE. Molecular identification of two novel Munc18 isoforms expressed in non-neuronal tissues. J Biol Chem 1995;270:5857-63.

25. Thurmond DC, Pessin JE. Molecular machinery involved in the insulin-regulated fusion of GLUT4-containing vesicles with the plasma membrane (review). Mol Membr Biol 2001;18:237-45.

26. Wang CC, $\mathrm{Ng}$ CP, Lu L, et al. A role of VAMP8/endobrevin in regulated exocytosis of pancreatic acinar cells. Dev Cell 2004; 7:359-71.

27. Gaisano HY, Sheu L, Whitcomb D. Alcohol chronic pancreatitis involves displacement of Munc18c from the pancreatic acinar basal membrane surface. Pancreas 2004;28:395-400.

28. Lee MG, Xu X, Zeng W, et al. Polarized expression of $\mathrm{Ca}^{2+}$ channels in pancreatic and salivary gland cells. Correlation with initiation and propagation of $\left[\mathrm{Ca}^{2+}\right]$ i waves. J Biol Chem 1997;272:15765-70.

29. Kasai H, Li YX, Miyashita Y. Subcellular distribution of $\mathrm{Ca}^{2+}$ release channels underlying $\mathrm{Ca}^{2+}$ waves and oscillations in exocrine pancreas. Cell 1993;74:669-77.

30. Husain SZ, Prasad P, Grant WM, Kolodecik TR, Nathanson MH, Gorelick FS. The ryanodine receptor mediates early zymogen activation in pancreatitis. Proc Natl Acad Sci USA 2005;102:14386-91.

31. Lundberg AH, Eubanks JW III, Henry J, et al. Trypsin stimulates production of cytokines from peritoneal macrophages in vitro and in vivo. Pancreas 2000;21:41-51.

32. Raraty MG, Murphy JA, Mcloughlin E, Smith D, Criddle D, Sutton R. Mechanisms of acinar cell injury in acute pancreatitis. Scand J Surg 2005;94:89-96.

33. Brady M, Bhatia M, Christmas S, Boyd MT, Neoptolemos JP, Slavin J. Expression of the chemokines MCP-1/JE and cytokine induced neutrophil chemoattractant in early acute pancreatitis. Pancreas 2002;25:260-9.

34. Satoh A, Gukovskaya AS, Edderkaoui M, et al. Tumor necrosis factor-alpha mediates pancreatitis responses in acinar cells via protein kinase $\mathrm{C}$ and proline-rich tyrosine kinase 2 . Gastroenterology 2005;129:639-51.

35. Tak PP, Firestein GS. NF-kappaB: A key role in inflammatory diseases. J Clin Invest 2001;107:7-11.

36. Satoh A, Gukovskaya AS, Nieto JM, et al. PKC-delta and-epsilon regulate NF-kappaB activation induced by cholecystokinin and TNF-alpha in pancreatic acinar cells. Am J Physiol Gastrointest Liver Physiol 2004;287:G582-91. 
37. Dugernier TL, Laterre PF, Wittebole X, et al. Compartmentalization of the inflammatory response during acute pancreatitis: Correlation with local and systemic complications. Am J Respir Crit Care Med 2003;168:148-57

38. McFadden DW. Organ failure and multiple organ system failure in pancreatitis. Pancreas 1991;6:S37-43.

39. Pooran N, Indaram A, Singh P, Bank S. Cytokines (IL-6, IL-8, TNF): Early and reliable predictors of severe acute pancreatitis. J Clin Gastroenterol 2003;37:263-6.

40. Norman JG, Fink GW, Denham W, et al. Tissue-specific cytokine production during experimental acute pancreatitis: A probable mechanism for distant organ dysfunction. Dig Dis Sci 1997;42:1783-8.

41. Virlos IT, Mazzon E, Serraino I, Thiemermann C, Siriwardena A, Cuzzocrea S. NF-kappaB inhibition by pyrrolidine dithiocarbamate attenuates experimental acute pancreatitis. Gastroenterology 2003;124:501-2A. (Abst)

42. Ethridge RT, Hashimoto K, Chung DH, Ehlers RA, Rajaraman S, Evers BM. Selective inhibition of NF-kappa B attenuates the severity of cerulein-induced acute pancreatitis. J Am Coll Surg 2002;195:497-505.

43. Bhatia M, Saluja AK, Hofbauer B, Lee HS, Frossard JL, Steer ML. The effects of neutrophil depletion on a completely noninvasive model of acute pancreatitis associated lung injury. Int J Pancreatol 1998;24:77-83.

44. Norman J, Yang J, Fink G, et al. Severity and mortality of experimental pancreatitis are dependent on interleukin-1 converting enzyme (ICE). J Interferon Cytokine Res 1997;17:113-8.

45. Denham W, Yang J, Fink G, et al. Gene targeting demonstrates additive detrimental effects of interleukin 1 and tumor necrosis factor during pancreatitis. Gastroenterology 1997;113:1741-6.

46. Frossard JL, Saluja A, Bhagat L, et al. The role of intercellular adhesion molecule 1 and neutrophils in acute pancreatitis and pancreatitis-associated lung injury. Gastroenterology 1999;116:694-701.

47. Lewis MP, Reber HA, Ashley SW. Pancreatic blood flow and its role in the pathophysiology of pancreatitis. J Surg Res 1998;75:81-9.

48. Werner J, Rivera J, Fernandez-del Castillo C, et al. Differing roles of nitric oxide in the pathogenesis of acute edematous versus necrotizing pancreatitis. Surgery 1997;121:23-30.

49. Qui B, Mei QB, Ma JJ, Korsten MA. Susceptibility to ceruleininduced pancreatitis in inducible nitric oxide synthase-deficient mice. Pancreas 2001;23:89-93.

50. Ueno N, Kashiwamura S, Ueda H, et al. Role of interleukin 18 in nitric oxide production and pancreatic damage during acute pancreatitis. Shock 2005;24:564-70.

51. Tiscornia OM, Martinez JL, Sarles H. Some aspects of human and canine macroscopic pancreas innervation. Am J Gastroenterol 1976;66:353-61.

52. Tiscornia OM, Hamamura S, Lehmann ES, et al. Biliary acute pancreatitis review. World J Gastroenterol 2000;6:157-68.

53. Cosen-Binker LI, Binker MG, Negri G, Tiscornia O. Influence of stress in acute pancreatitis and correlation with stress-induced gastric ulcer. Pancreatology 2004;4:470-84.

54. Salvioli B, Bovara M, Barbara G, et al. Neurology and neuropathology of the pancreatic innervation. JOP 2002;3:26-33.

55. Kiernan J. Interaction between mast cells and nerves. Neurogenic inflammation. Trends Pharmacol Sci 1990;11:316.

56. Cosen-Binker LI, Binker MG, Negri G, Tiscornia O. Experimental model of acute pancreatitis in Wistar rat: Glucocorticoid treatment profile. Dig Dis Sci 2003;48:1453-64.

57. Cosen-Binker LI, Binker MG, Negri G, Tiscornia O. Acute pancreatitis possible initial triggering mechanism and prophylaxis. Pancreatology 2003;3:445-56.

58. Savkovic V, Gaiser S, Iovanna JL, Bodeker H. The stress response of the exocrine pancreas. Dig Dis 2004;22:239-46.

59. Iovanna J, Lechene de la Porte P, Dagorn JC. Expression of genes associated with dedifferentiation and cell proliferation during pancreatic regeneration following acute pancreatitis. Pancreas 1992;7:712-8.

60. Schafer C, Williams JA. Stress kinases and heat shock proteins in the pancreas: Possible roles in normal function and disease. J Gastroenterol 2000;35:1-9.

61. Rakonczay Z Jr, Takacs T, Boros I, Lonovics J. Heat shock proteins and the pancreas. J Cell Physiol 2003;195:383-91.
62. Tashiro M, Ernst SA, Edwards J, Williams JA. Hyperthermia induces multiple pancreatic heat shock proteins and protects against subsequent arginine-induced acute pancreatitis in rats. Digestion 2002;65:118-26.

63. Otaka M, Itoh H, Kuwabara T, et al. Induction of heat shock protein and prevention of cerulein-induced pancreatitis by waterimmersion stress in rats. Int J Biochem 1994;26:805-11.

64. Wagner AC, Weber H, Jonas L, et al. Hyperthermia induces heat shock protein expression and protection against cerulein-induced pancreatitis in rats. Gastroenterology 1996;111:1333-42.

65. Kubisch C, DiMagno MJ, Tietz AB, et al. Overexpression of heat shock protein $\mathrm{Hsp} 27$ protects against cerulein-induced pancreatitis. Gastroenterology 2004;127:275-86.

66. Frossard JL, Pastor CM, Hadengue A. Effect of hyperthermia on NF-kappaB binding activity in cerulein-induced acute pancreatitis. Am J Physiol Gastrointest Liver Physiol 2001;280:G1157-62.

67. Iovanna JL, Keim V, Nordback I, et al. Serum levels of pancreatitis associated protein as indicators of the course of acute pancreatitis. Multicentric Study Group on Acute Pancreatitis. Gastroenterology 1994:106:728-34.

68. Malka D, Vasseur S, Bodeker H, et al. Tumor necrosis factor alpha triggers antiapoptotic mechanisms in rat pancreatic cells through pancreatitis-associated protein I activation. Gastroenterology 2000;119:816-28.

69. Vasseur S, Folch-Puy E, Hlouschek V, et al. p8 improves pancreatic response to acute pancreatitis by enhancing the expression of the anti-inflammatory protein pancreatitis-associated protein I. J Biol Chem 2004;279:7199-207.

70. Heller A, Fiedler F, Schmeck J, Luck V, Iovanna JL, Koch T. Pancreatitis-associated protein protects the lung from leukocyteinduced injury. Anesthesiology 1999;91:1408-14.

71. Encinar JA, Mallo GV, Mizyrycki C, et al. Human $\mathrm{p} 8$ is a HMGI/Y-like protein with DNA binding activity enhanced by phosphorylation. J Biol Chem 2001;276:2742-51.

72. Garcia-Montero A, Vasseur S, Giono LE, et al. Transforming growth factor beta-1 enhances Smad transcriptional activity through activation of $\mathrm{p} 8$ gene expression. Biochem J 2001;357:249-53

73. Vasseur S, Hoffmeister A, Garcia-Montero A, et al. p8-deficient fibroblasts grow more rapidly and are more resistant to adriamycin induced apoptosis. Oncogene 2002;21:1685-94.

74. Ropolo A, Tomasini R, Grasso D, et al. Cloning of IP15, a pancreatitis-induced gene whose expression inhibits cell growth. Biochem Biophys Res Commun 2004;319:1001-9.

75. Dusetti NJ, Jiang Y, Vaccaro MI, et al. Cloning and expression of the rat vacuole membrane protein 1 (VMP1), a new gene activated in pancreas with acute pancreatitis, which promotes vacuole formation. Biochem Biophys Res Commun 2002;290:641-9.

76. Vaccaro M, Grasso D, Ropolo A, Iovanna JL, Cerquetti MC. VMP expression correlates with acinar cell cytoplasmic vacuolization in arginine-induced acute pancreatitis. Pancreatology 2003;3:69-74.

77. Gukovskaya AS, Pandol SJ. Cell death pathways in pancreatitis and pancreatic cancer. Pancreatology 2004:4:567-86.

78. Matej R, Housa D, Olejar T. Acute pancreatitis: Proteinaseactivated receptor-2 as Dr. Jekyll and Mr. Hyde. Physiol Res 2005. (In press)

79. Maire F. [Genetic testing for acute or chronic pancreatitis]. Gastroenterol Clin Biol 2005;29:715-23.

80. Hanck C, Schneider A, Whitcomb DC. Genetic polymorphisms in alcoholic pancreatitis. Best Pract Res Clin Gastroenterol 2003;4:613-23

81. Simon P, Weiss FU, Zimmer KP, Koch HG, Lerch MM. Acute and chronic pancreatitis in patients with inborn error of metabolism. Pancreatology 2001;1:448-56.

82. Whitcomb D. Acute pancreatitis: Molecular biology update. J Gastrointest Surg 2003;7:940-2.

83. Lowenfels A, Maisoneuve P, Whitcomb D. Risk factors for cancer in hereditary pancreatitis. International Hereditary Pancreatitis Study Group. Med Clin North Am 2000;84:565-73.

84. Whitcomb D. Genetic predisposition to alcoholic pancreatitis. Pancreas 2003;27:321-6.

85. Riordan JR, Rommens JM, Kerem B, et al. Identification of the cystic fibrosis gene: Cloning and characterization of complementary DNA. Science 1989;245:1066-73.

86. Welsh MJ, Smith AE. Molecular mechanisms of CFTR chloride channel dysfunction in cystic fibrosis. Cell 1993;73:1251-4. 
87. Durie PR. Pancreatitis and mutations of the cystic fibrosis gene. N Engl J Med 1998;339:687-8.

88. Purohit V, Russo D, Salin M, Brown R. Mechanisms of alcoholic pancreatitis: Introduction and summary of the symposium. Pancreas 2003;27:281-5.

89. Schneider A, Whitcomb DC, Singer MV. Animal models in alcoholic pancreatitis - What can we learn? Pancreatology 2002;2:189-203.

90. Pandol SJ, Periskic S, Gukovsky I, et al. Ethanol diet increases the sensitivity of rats to pancreatitis induced by cholecystokinin octapeptide. Gastroenterology 1999;117:706-16.

91. Saluja AK, Bhagat L. Pathophysiology of alcohol-induced pancreatic injury. Pancreas 2003;27:327-31.

92. Jerrells TR, Chapman N, Clemens DL. Animal model of alcoholic pancreatitis: Role of viral infections. Pancreas 2003;27:301-4.

93. Gukovskaya AS, Hosseini S, Satoh A, et al. Ethanol differentially regulates NF-kappaB activation in pancreatic acinar cells through calcium and protein kinase C pathways. Am J Physiol Gastrointest Liver Physiol 2004;286:G204-13.

94. Haber PS, Apte MV, Applegate TL, et al. Metabolism of ethanol by rat pancreatic acinar cells. J Lab Clin Med 1998;132:294-302.

95. Hamamoto T, Yamada S, Hirayama C. Nonoxidative metabolism of ethanol in the pancreas; Implication in alcoholic pancreatic damage. Biochem Pharmacol 1990;39:241-5.
96. Rosado JA, Gonzalez A, Salido GM, Pariente JA. Effects of reactive oxygen species on actin filament polymerization and amylase secretion in mouse pancreatic acinar cells. Cell Signal 2002;14:547-56.

97. McKim SE, Uesugi T, Raleigh JA, McClain CJ, Arteel GE. Chronic intragastric alcohol exposure causes hypoxia and oxidative stress in the rat pancreas. Arch Biochem Biophys 2003;417:34-43.

98. Li HS, Zhang JY, Thompson BS, et al. Rat mitochondrial ATP synthase ATP5G3: Cloning and upregulation in pancreas after chronic ethanol feeding. Physiol Genomics 2001;6:91-8.

99. Lee HC, Wei YH. Mitochondrial role in life and death of the cell. J Biomed Sci 2000;7:2-15.

100. Weber H, Huhns S, Luthen F, Jonas L, Schuff-Werner P. Calpain activation contributes to oxidative stress-induced pancreatic acinar cell injury. Biochem Pharmacol 2005; 70:1241-52.

101. Haber PS, Wilson JS, Apte MV, Pirola RC. Fatty acid ethyl esters increase pancreatic lysosome fragility. J Lab Clin Med 1993;121:759-64.

102. Gorelick FS. Alcohol and zymogen activation in the pancreatic acinar cell. Pancreas 2003;27:305-10.

103. Rinderknecht H, Stace NH, Renner IG. Effects of chronic alcohol abuse on exocrine pancreatic secretion in man. Dig Dis Sci $1985 ; 30: 65-71$ 


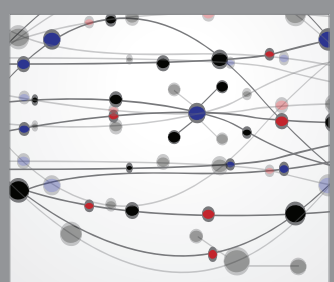

The Scientific World Journal
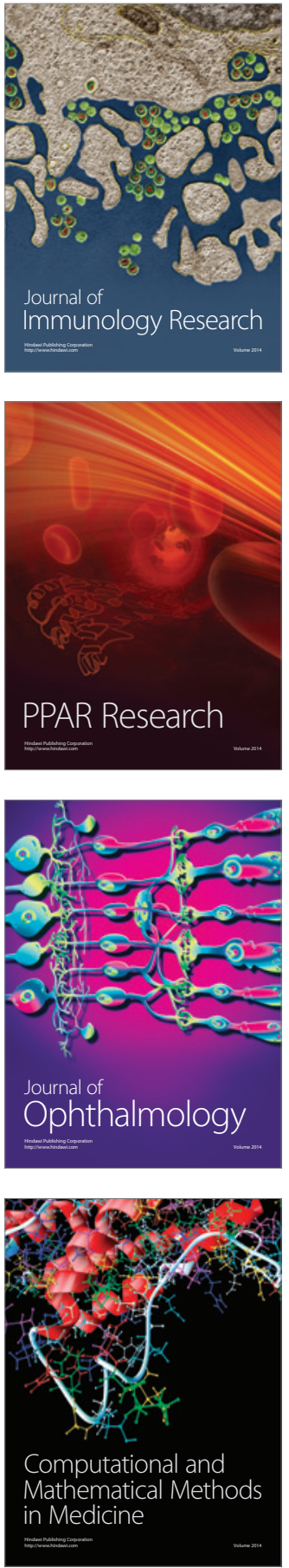

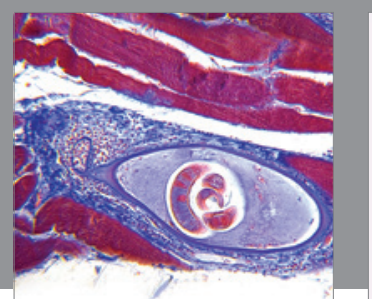

Gastroenterology Research and Practice

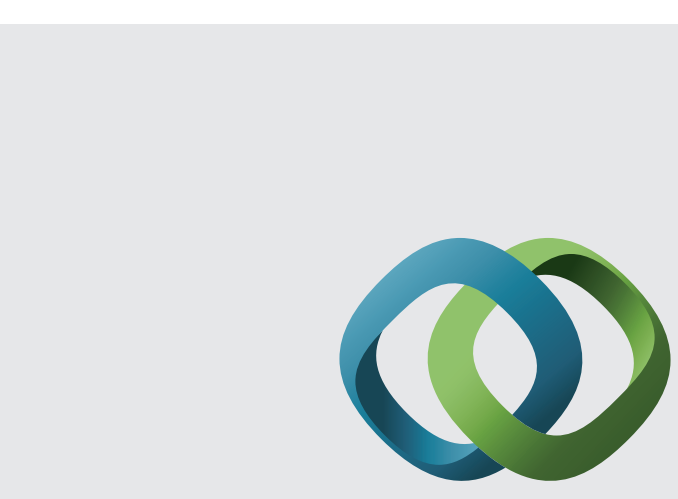

\section{Hindawi}

Submit your manuscripts at

http://www.hindawi.com
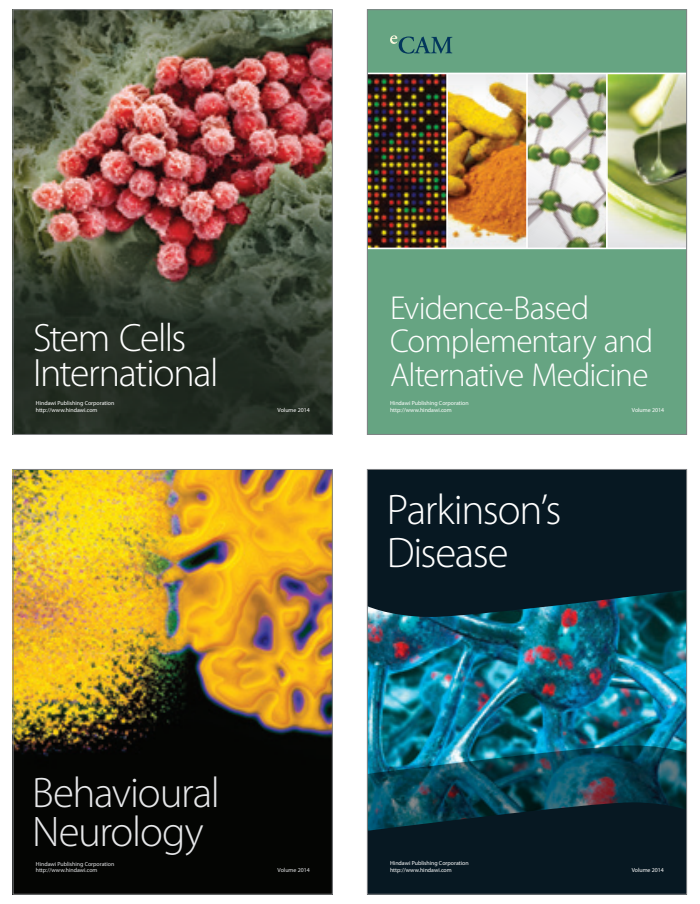
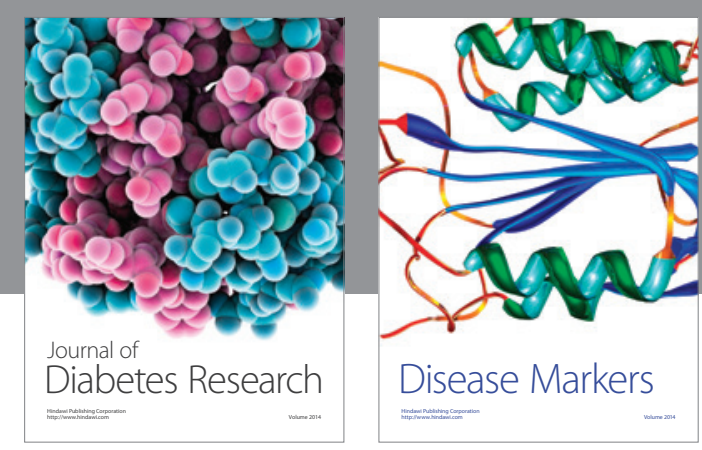

Disease Markers
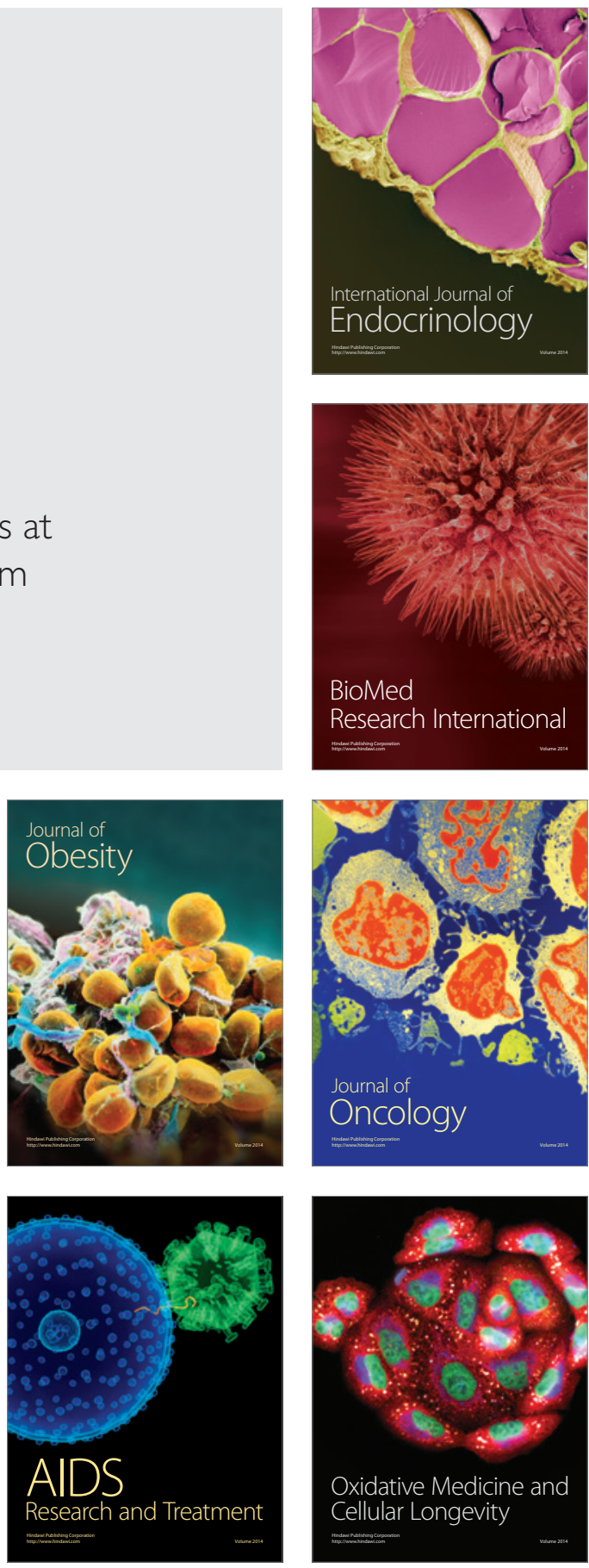